\title{
Geomorphological indicators of large-scale climatic changes in the Eastern Bolivian lowlands
}

\section{Jan-Hendrik May, Berne}

\section{Introduction}

Late Quaternary tropical paleoclimatic research has become successively more important for our understanding of the global climate system. However, the major part of paleoclimatic data in tropical South America still originates from the Andean highlands. Data from the tropical lowlands are relatively scarce and in some cases contradictory. Without additional records from the tropical lowlands, any conclusion regarding the paleoclimatic history of tropical South America will thus be biased (Coltrinari 1993). Situated at the transition zone between the tropical-humid and the subtropical semi-arid climatic regimes, the Eastern Bolivian lowlands (EBL) are therefore particularly suited for the detection of large-scale climate changes.

Up to now, only few studies have been concerned with the geomorphology, landscape evolution and paleoclimatic history of the EBL. A general geomorphological overview is provided by WERDING (1977) and IRIONDO (1993). Servant et al. (1981) conducted first studies of paleosol-sediment-sequences, and only recently MAYLE et al. (2000) and BURBridge et al. (2004) published results of vegetation and climate reconstructions deduced from pollen analysis in Northeastern Bolivia. Another pollen record comes from a bog within the Andean cloud forest (Mourguiart \& Ledru 2003).

This study provides a revised inventory of geomorphological landforms in Eastern Bolivia at various spatial scales, benefiting from the increased availability and simplified use of remote sensing data (UNIVERSITY OF MaRYLAND 2005). In combination with field studies remote sensing turned out to be a powerful tool for area-wide geomorphological mapping. Landforms and landform associations are interpreted and discussed regarding landscape evolution and paleoclimatic history. This is the base for further and more detailed paleoclimatic research currently conducted in Eastern Bolivia.

\section{Study area}

Mountain building and Andean deformation associated with the subduction of the Nazca plate has pro- gressively migrated eastward throughout the Cenozoic (GubBels et al.1993; IsACKs 1988), leading to the thickening and horizontal shortening of the continental crust and the formation of the Eastern Cordillera and the Subandean zone (Fig. 1). At least since Miocene times, the erosional products of active deformation in the Subandean zone have been transported into the foreland of Eastern Bolivia (GubBels et al. 1993). Therefore, the Eastern Bolivian lowlands are a retroarc foreland basin system with the Chaco Plain $\left(\sim 18^{\circ}\right.$ $24^{\circ} \mathrm{S}$ ) being one of several active depocenters adjacent to the Central Andes (Horton \& DeCelles 1997).

The Subandean foothills can be regarded as the topographic transition from the Subandean zone into the foreland basin (Fig. 1). To the east, active deformation structures are buried beneath Cenozoic sediments (Hinsch et al. 2002; Horton \& DeCelles 1997), which thin out towards the east and onlap the pre-Andean basement. The northeastern margin of the Chaco plain is delimited by the outcrop of the Precambrian Brazilian shield. The transition between the Chaco plain and the Brazilian shield is interrupted by the Chiquitana ranges consisting mainly of sedimentary rocks of the Palaeozoic Chaco basin. Palaeozoic rocks are unconformably overlain by a thin cover of Mesozoic rocks (WeLSINK et al. 1995) and extend onto a topographic and structural high to the south (Izozog arch) representing the flexural forebulge of the Andean deformation (HorTon \& DeCELLEs 1997).

The present climatic conditions of the EBL reflect their location between the tropical wet climate regime of the Amazon basin and the subtropical semi-arid climate to the south. During austral summer, the South American summer monsoon (SASM) dominates the atmospheric circulation over most of continental South America (Nogues-PAEgle et al. 2002; Zhou \& LAU 1998). NE-trade winds are responsible for moisture advection from the tropical Atlantic into the Amazon basin. From there, the southward transport of the Amazonian moisture into the EBL and towards the South Atlantic convergence zone (SACZ) is accomplished by the South American low level jet (SALLJ) (BERRI \& INZUNZa 1993). The SALLJ is a strong N-S wind system east of the Andes active throughout the year (SAulo et al. 2004). However, due to the lack of topographic barriers, cold air incursions from mid-latitude South America periodically penetrate deep into the Amazon basin (Garreaud 2000) leading to significant lowering of temperatures and enhanced precipi- 


\begin{tabular}{|l|l|l|l|}
\hline Mission / Data & Spatial Resolution & Spectral Resolution & Temporal Frame \\
\hline LANDSAT MSS & $80 \mathrm{~m}$ & multispectral & $1972-1992$ \\
LANDSAT TM & $30-120 \mathrm{~m}$ & multispectral & 1982 -present \\
LANDSAT ETM & $15-60 \mathrm{~m}$ & multispectral & $1999-$ present \\
ASTER & $15-90 \mathrm{~m}$ & multispectral & $2000-$ present \\
CORONA & $3-5 \mathrm{~m}$ & panchromatic & $1960-1972$ \\
MODIS & $250-1000 \mathrm{~m}$ & multispectral & 2000 -present \\
AERIAL PHOTOS & $1-2 \mathrm{~m}$ & panchromatic & 1960 's \\
SRTM & $30-90 \mathrm{~m}$ & - & February-2000 \\
\hline
\end{tabular}

Tab. 1: Remote sensing data used for geomorphological mapping and its characteristics Verwendete Fernerkundungsdaten für die geomorphologische Kartierung und ihre Charakteristika Caractéristiques des données issues de la télédétection utilisées pour la cartographie géomorphologique Source: U.S. Geological SuRvey 2005

tation during austral winter (Garreaud 2000; Pezza \& AmbrizZI 2005).

Precipitation amounts and distribution in Eastern Bolivia depend to a large extent on the SASM and its components. Total annual precipitation decreases from $\sim 1500 \mathrm{~mm} / \mathrm{a}$ at $17^{\circ} \mathrm{S}$ to $<500 \mathrm{~mm} / \mathrm{a}$ at $21^{\circ}$ (AgroteCNologica Amazonica 2005). This trend is accompanied by increasing duration of the dry season (seasonality) towards the south. Most precipitation $(\sim 40 \%)$ falls as a direct result of convective activity during the rainy season in the months of December to February. The distribution of potential vegetation and ecosystems largely reflects the present climatic conditions. IBISCH et al. (2004) differentiate between four ecoregions: The Amazon evergreen forests and the semi-deciduous Chiquitano dry forest in the north grade into the open and wooded savannas of the Cerrado formations in the east and into the low deciduous dry forest of the Gran Chaco in the south.

\section{Methods}

In order to achieve a complete coverage of the study area, various kinds of remote sensing data have been integrated within this study. Increased availability and improved management of satellite imagery on a low-cost basis have made the use of these data efficient (UNiversity of Maryland 2005; U.S. GeologiCAL SuRvey 2005). Depending on their characteristics (Table 1), different types of data have been used for different purposes.

For the detection and mapping of geomorphological features from remote sensing data, various methods have been proposed in the literature, each applying to a specific purpose of mapping (BARSCH \& LiEDTKE
1980). The deduction of landscape evolution (genetic geomorphology) results from comparison of past landforms and present processes. This requires spatially and temporally diverse information. Visual interpretation incorporates colour, density and texture of the imagery, but also deduces information from elevation, vegetation and land-use patterns (VERSTAPPEN 1977). Apart from the remote sensing data, this study integrates information collected during several months of field work conducted over three years from 20032005.

\section{Results}

The EBL can be outlined following structural and topographic criteria. In contrast to the adjacent Andes to the west and the Brazilian shield to the east, the generally low relief is due to active sedimentation processes throughout the recent geological past. The visualization and analysis of digital elevation data allows the subdivision of the lowlands into three distinct geomorphological units (Fig. 1):

- A1 and A2: alluvial slopes of the piedmont (northern and southern part) bordering the Subandean zone:

- B1, B2 and B3: fluvial megafans of the three large river systems in the study area from south to north (Río Parapetí, Río Grande and Río Piray);

- C: topographically elevated upland areas corresponding to the structural high of the Andean forebulge.

These units are genetically distinct macro-scale geomorphological landforms. Their age and evolution have to be considered within the context of the formation of the Andes extending back into the Tertiary 

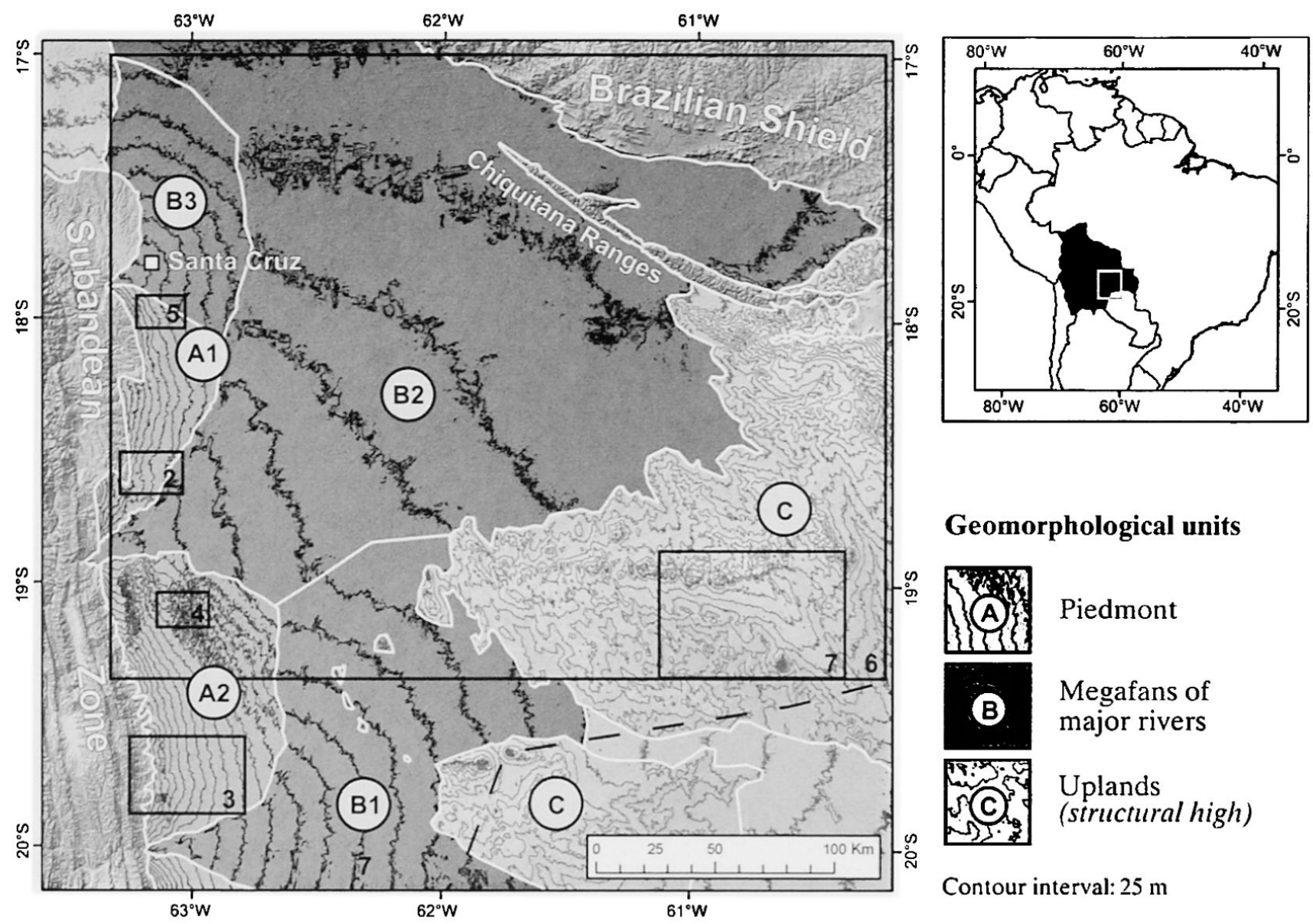

Geomorphological units

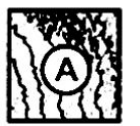

Piedmont

(B) Megafans of

major rivers

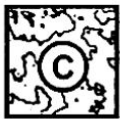

Uplands

(structural high)

Contour interval: $\mathbf{2 5} \mathrm{m}$

Fig. 1: Macro-scale geomorphological units in the study area as deduced from digital elevation data (black boxes refer to location of figures)

Geomorphologische Grosseinheiten im Untersuchungsgebiet, abgeleitet von digitalen Höhendaten (schwarze Kästchen beziehen sich auf die Lage der Abbildungen)

Unités géomorphologiques de la zone d'étude à grande échelle, issues des données numériques d'altitude (les rectangles noirs indiquent la localisation des images)

Source: SRTM 90-m data, Global Land Cover Facility http://www.landcover.org.

(BaKer 1986; Horton \& DeCelles 1997). On shorter timescales focussing on late Quaternary landscape and climate history, present processes typical for each of these three landscape elements can be compared to relict landform generations. Thus it is possible to detect changes in geomorphic processes over time, which in turn serves as indicator for changes in the controlling parameters of landscape evolution, namely tectonics, climate and humans (Sснимm 1999; SumMERFIELD 2000).

\subsection{Piedmont}

The Andean piedmont forms the transition zone between the Subandean ranges and the fluvial systems of the large rivers of Eastern Bolivia. Morphologically, it is a gently eastward inclined slope. Low slope angles of $\sim 0.35-0.55 \%$ and the apparent lack of alluvial fan morphology indicate that confined stream flow is the main process of piedmont construction (SMIтH 2000). With the piedmont being a typical alluvial slope, paleoclimatic implications may be derived from its sedimentological architecture and the reconstruction of paleohydrology.

In the study area, the piedmont can be subdivided into a northern and a southern part (A1 and A2) separated by the Río Grande megafan. Both parts are situated in climatically different environments, with the northern part being characterized by higher total annual precipitation and less pronounced seasonality. Therefore differences in type and intensity of the dominant geomorphic processes can be expected.

\subsubsection{Drainage network}

The Subandean foothills are the catchment areas of the piedmont (Fig. 2). Bordered by a topographically 


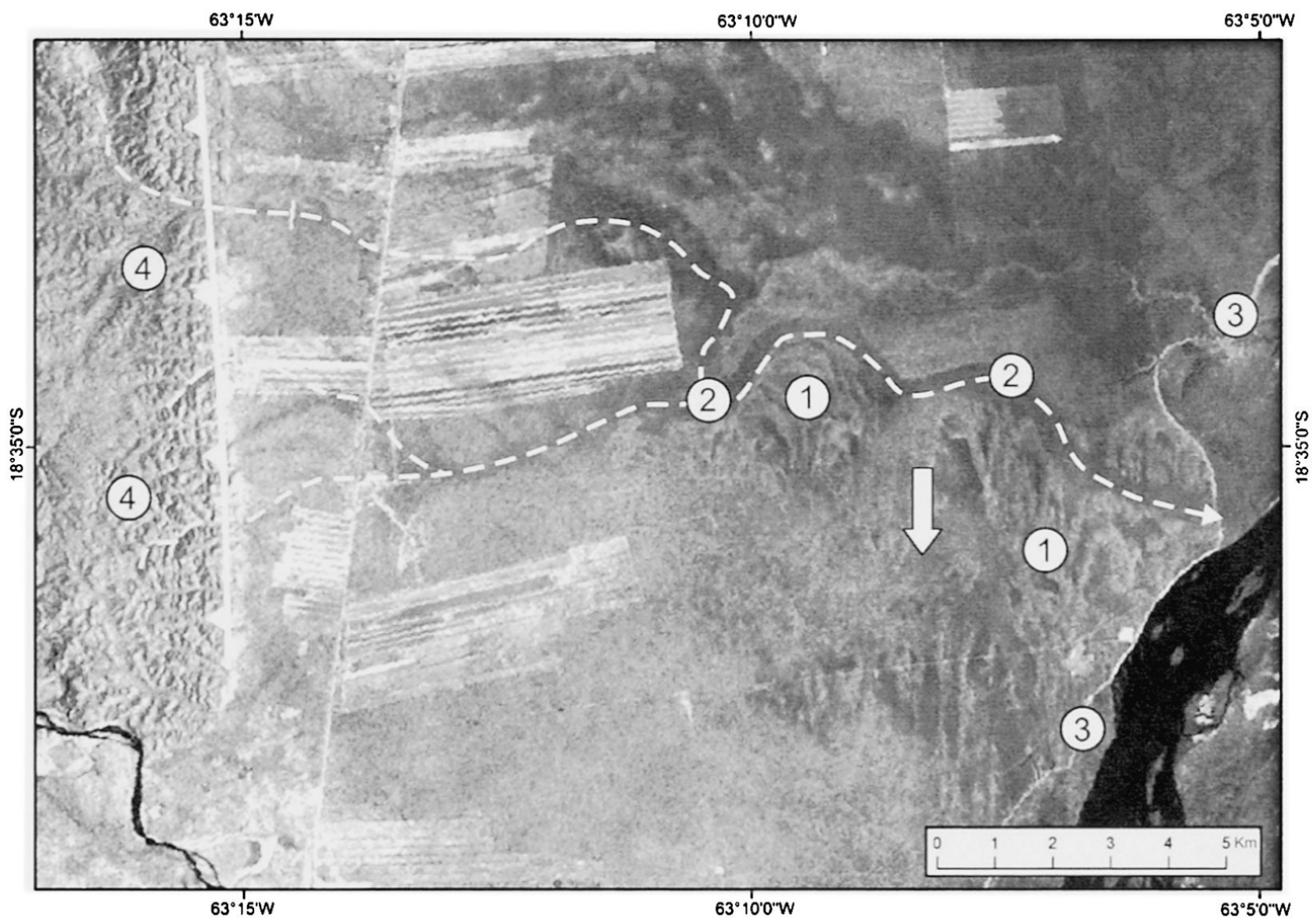

Fig. 2: Paleodunes (1) and largely inactive drainage channels (white dashed lines, 2) are the most characteristic features on the piedmont between the erosional scarp (3) of the Río Grande and the uplifted and dissected Subandean foothills (4) (arrow = paleowind direction).

Paläodïnen (1) und grösstenteils inaktive Gerinnebetten (weisse gestrichelte Linien, 2) sind die charakteristischen Formen auf dem Piedmont zwischen Erosionsterrasse des Rio Grande (3) und den gehobenen, zerschnittenen Subandinen Vorbergen (4) (Pfeil = Paläo-Windrichtung).

Paléodunes (1) et chenaux de drainage en grande partie inactifs (lignes discontinues, 2) sont des éléments distinctifs du piémont situé entre l'escarpment érosif du Rio Grande (3) et les collines élevées et découpées subandines (4) (la flèche indique la direction du paléovent).

Source: Landsat TM 230-73, Band combination 5-4-3, Global Land Cover Facility http://www.landcover.org.

sharp thrust-fault, they are characterized by a highly integrated drainage network at an advanced stage of dissection. Today the entire area is covered by dense forest and drainage channels within the foothills are largely inactive. Floodplains and channel beds do not show evidence of active sediment transport on the piedmont. In some cases valleys several hundred meters wide are presently not occupied by any recognizable stream. Therefore the dissection of the foothills must have occurred under past climatic conditions different from today.

The drainage network on the piedmont follows the inclination of the piedmont slope. No drainage channels presently reach the Río Grande or Río Parapetí.
Active floodplains and significant sediment transport on the piedmont have only been observed in the northern part of the piedmont $(\mathrm{A} 1)$ in the vicinity of Santa Cruz and along the southern part of the piedmont (A2). In both areas the drainage channels have incised into the proximal part of the piedmont surface. In between these areas, the drainage channels are essentially inactive and do not show any evidence for either sediment transport or incision (Fig. 2).

Along the southern piedmont the drainage channels deposit their bed-load when emerging from the incised reach of the channel (Fig. 3). This process causes a delta-shaped lobe of coarse fluvial sediments referred to as floodout (TоOтн 2000). These floodouts seem to 


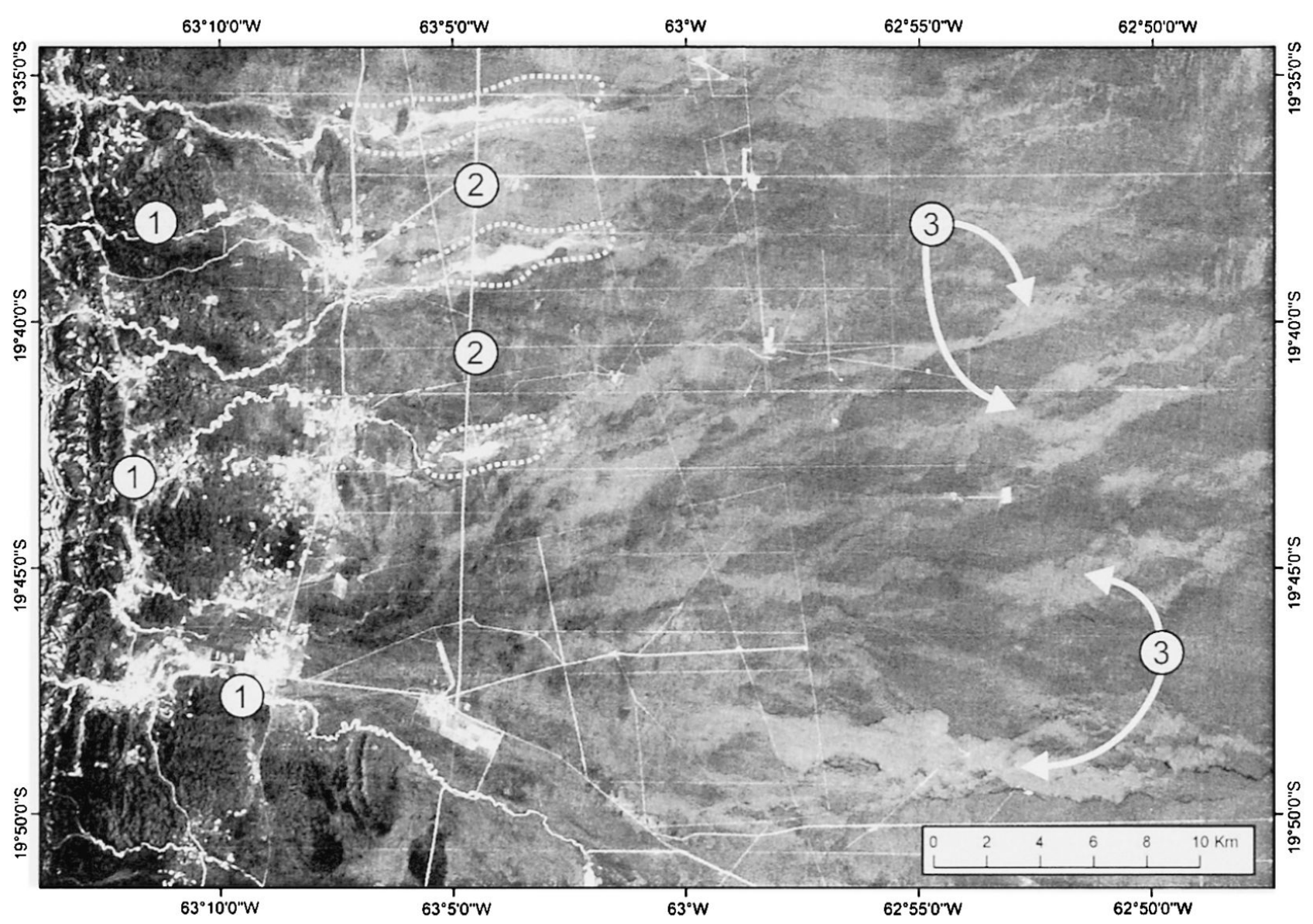

Fig. 3: Incised drainage channels (1), floodouts (2) and area of paleo-floodouts (3) along the southern piedmont Eingeschnittene Gerinne (1), "floodouts» (2) und Zone der Paläo-«floodouts" (3) entlang des südlichen Piedmont

Chenaux de drainage incisés (1), zones de débordement ("floodouts») (2) et paléozones de débordement (3) le long du piémont sud

Source: Landsat TM 230-74, Band combination 3-2-1, Global Land Cover Facility http://www.landcover.org.

have been located significantly further downslope in the past as evident from large areas of reduced density of forest cover. The shift of the floodouts to the proximal parts of the piedmont probably indicates reduced intensities of the discharge events.

\subsubsection{Paleodunes}

The most characteristic geomorphological features along the northern part of the piedmont are several paleodune fields (Fig. 2). They all consist of NW-SE to $\mathrm{N}$-S trending parabolic dune forms, corresponding to the dominant wind direction (AGROTECNOLOGICA AMAZONICA 2005). The parabolic dune forms indicate a uniform wind regime and the presence of a vegetation cover dense enough to fix the lateral limbs of the dunes during dune migration (MCKEE 1979). In some cases the limbs are several kilometres long, implying a high movement rate and/or a relatively long time period of dune activity. Paleodune systems have only been observed along the southern margins of drainage channels. Apparently, past dune formation was closely tied to sufficient sediment supply. Both, the fluvial transport of sediment out of the Subandean catchments onto the piedmont, and the subsequent aeolian reworking most likely indicate generally drier climatic conditions with reduced forest cover, intensified discharge events and a prolonged dry season.

A large dune field (Lomas de Guanacos) exists on the southern part of the piedmont (Fig. 4,6). It is largely inactive today. Its size $\left(\sim 2,250 \mathrm{~km}^{2}\right)$ as well as its position along the southern border of the Río Grande megafan point to the Río Grande as the source of the aeolian sands that build up the Lomas de Guanacos. In contrast to the smaller paleodune formations to the north, the Lomas de Guanacos exhibit a complex internal structure. Three dune generations can be distinguished. The peripheral parts of the dune field consist of long, N-S 


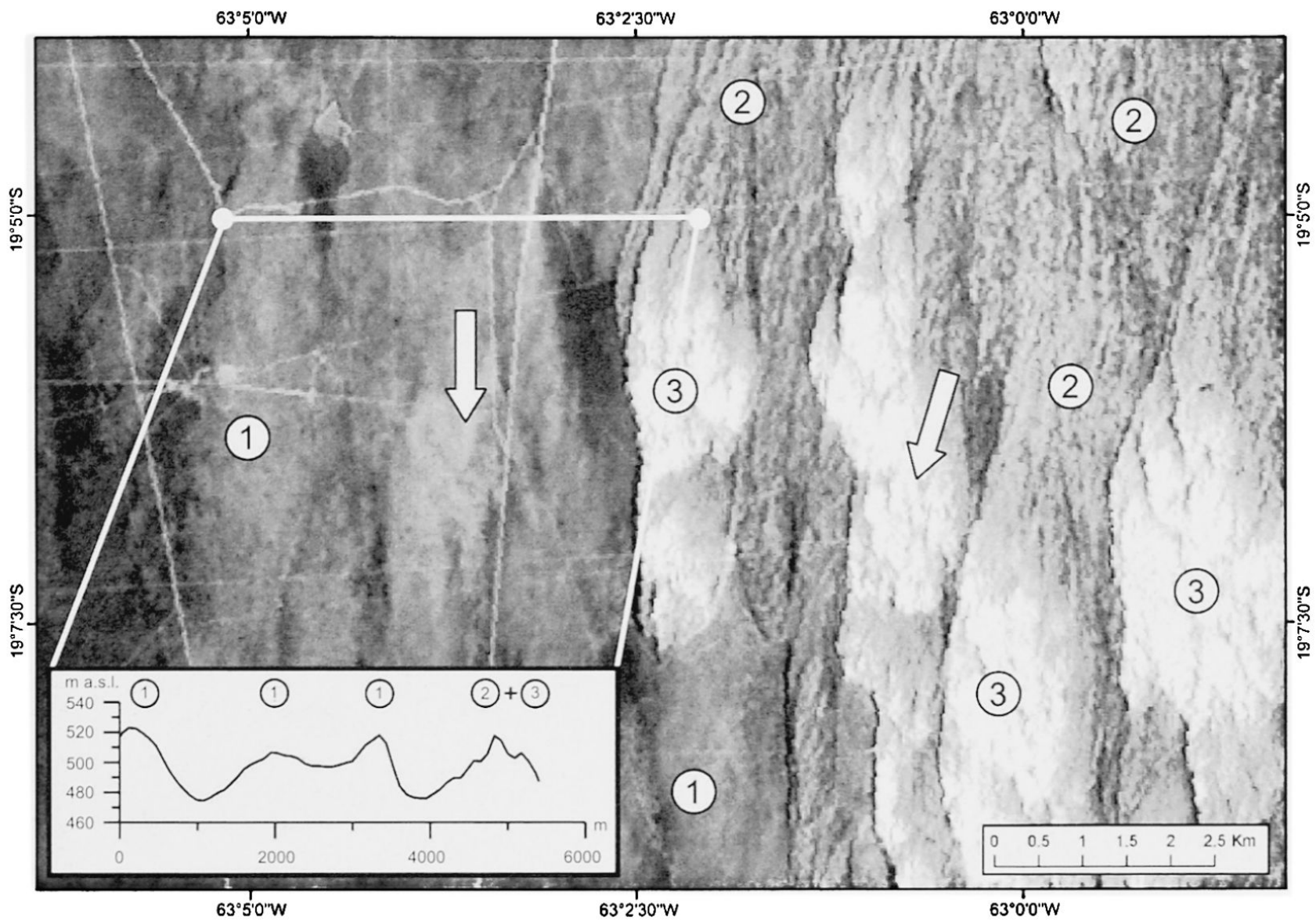

Fig. 4: Paleodune field of the Lomas de Guanacos with oldest dune generation (1), younger formations (2) and active dunes (3) (arrow = paleowind direction)

Paläodünenfeld Lomas de Guanacos mit ältester Dünengeneration (1), jüngeren Formationen (2) und aktiven Dünen (3) (Pfeil = Paläo-Windrichtung)

Champ de paléodunes de Lomas de Guanacos montrant la génération la plus ancienne (1), les formations plus jeunes (2) et les dunes actives (3) (la flèche indique la direction du paléovent)

Source: Landsat ETM 230-73, Band combination 5-3-3, Global Land Cover Facility http://www.landcover.org.

trending dune ridges. These ridges are interpreted as limbs of large parabolic dunes. They show a smooth morphology, which points to fluvial erosion after their fixation and indicates a relatively old age. Towards the central part, the Lomas de Guanacos are characterized by a more undulating surface morphology and smaller parabolic forms. Within this younger generation, inactive dunes have been distinguished from active dunes based on the density of forest cover. A marked change in paleowind strength and/or direction must have occurred between the formation of the older and the younger dune generations, as the NNE-SSW direction of the younger generation does not correspond to the $\mathrm{N}$-S direction of older dunes (Fig. 4).

\subsubsection{Active dunes}

Two active dune complexes form the nucleus of a dune field (Lomas de Arena) about $15 \mathrm{~km}$ south of Santa
Cruz (Fig. 5). The dune fronts actively advance into the forest, forming a large parabolic dune with limbs of various kilometres length. Most of the active inner dunes, however, are barchanoid forms, illustrating the missing influence of vegetation on dune mobility (MCKeE 1979).

The evolution of the Lomas de Arena has passed through at least two distinct phases. This is evident from the inactive paleodunes surrounding the active dune fields. Sand deflation and initiation of dune migration is presently observed along the floodplains of various small drainage channels (JoRDAN 1981), suggesting that, apart from the Rio Piray, the Subandean foothills are an essential source of the aeolian sands. The ongoing activity of the Lomas de Arena dune fields is therefore probably closely tied to the development of the drainage channels. This exam- 


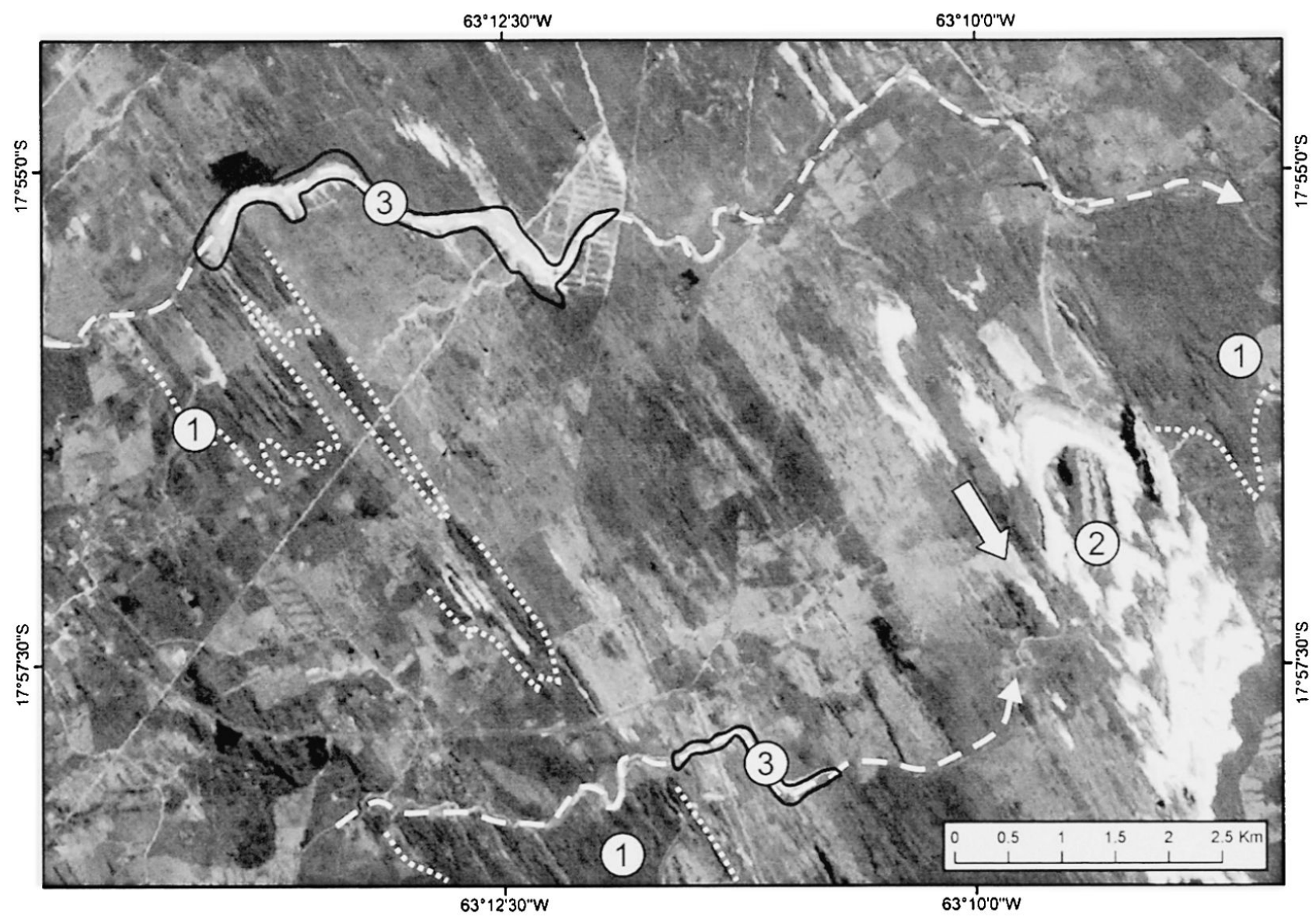

Fig. 5: Paleodunes (dotted, 1) and active dunes within the Lomas de Arena dune field; deflation on restricted floodplain areas (3) (arrow $=$ paleowind direction)

Paläodïnen (gepunktet, 1) und aktive Dünen im Dïnenfeld Lomas de Arena; Deflation in kleinen Teilen des Flussbettes (3) (Pfeil = Paläo-Windrichtung)

Paléodunes (pointillés, 1) et dunes actives du champ dunaire de Lomas de Arena; déflation dans certaines parties de la plaine alluviale (3) (la flèche indique la direction du paléovent)

Source: ASTER VNIR 231-72, L1B.003:2003834450, Band combination 2-3-1, EROS Data Center http://eros. usgs.gov.

ple illustrates that dune formation does not require desert like conditions, but sufficient sediment supply, strong winds and a pronounced dry season in order to transfer the material out of the floodplains. Based on the extent and occurrence of paleo- and active dunes, areas prone to present deflation and dune formation are apparently more restricted (Fig. 5). Increased discharge intensity and sediment supply may also have played a role during the initial evolution of the Lomas de Arena.

\subsection{Megafans}

Three fluvial megafans have been formed by the three major rivers in Eastern Bolivia. The Río Piray megafan northeast of Santa Cruz de la Sierra $\left(\sim 4,300 \mathrm{~km}^{2}\right)$ is the smallest one; the Río Grande megafan $\left(\sim 37,500 \mathrm{~km}^{2}\right)$ and the Río Parapetí megafan $\left(\sim 15,000 \mathrm{~km}^{2}\right)$ are con- siderably larger. Megafans are characteristic for large subtropical rivers (Leier et al. 2005) and show a downstream zonation depending on the hydrological and geomorphological characteristics of each megafan (SHuKLa et al. 2001). Shifts in the zonation are therefore likely to reflect paleoclimatic and paleohydrological changes in the megafan.

Today, the Río Parapetí (B1) flows along the northwestern margin of its megafan. Several paleochannels of the Río Parapetí can be reconstructed from vegetation differences on the megafan. The pattern of the paleochannels implies a northward shift of the river course through time. Based on the topographic data, the southernmost paleochannel can be traced into Paraguay, where it formerly contributed to the Río de la Plata basin (BArboza et al. 2000). 
Along the southern megafan margin, the oldest visible paleo-channel grades into a large paleodune field $\left(14,500 \mathrm{~km}^{2}\right)$, exclusively composed of parabolic dunes. It extends almost to the Argentinean border and into Paraguay. The Río Parapetí probably maintained its southern position for a prolonged period of time before the onset of the northward shift. Parabolic paleodunes occur along the southern margins of all paleochannels. They are larger than the active dunes along the present channel, indicating increased sediment supply and enhanced deflation during the time of channel migration.

At about $19^{\circ} \mathrm{S}$ the Río Parapetí deposits most of its coarse sediment load within a highly migrational inland delta, the wetlands of the Bañados de Izozog. A large paleodune field of mainly parabolic and longitudinal morphology exists along the southeastern margin of the Bañados de Izozog in the Kaa' Iya National Park (Fig. 6). Based on the large size of this paleodune field $\left(800 \mathrm{~km}^{2}\right)$ it may be assumed that a former channel of the Río Grande was the source of the aeolian sands.

Near the proximal part of the megafan, the Río Parapetí has formed two distinct terrace levels corresponding to enhanced incision, probably indicating decreasing sediment loads at the transition to wetter conditions and increased humidity.

The present course of the Río Grande (B2) is confined to the northwestern margin of the megafan (Fig. 6). In analogy to the Parapetí megafan, several paleochannels exist due to a northward shift of the river channel from a formerly W-E direction towards the present SW-NE-NW direction. At the eastern border of the Río Grande megafan the Río Parapetí cuts through the Chiquitana ranges at the Quimome gap (Fig. 6). This gap is probably an antecedent gorge resulting from stable discharge conditions over a long period of time. The antecedence is assumed to be inherited from the formerly W-E flowing Río Grande under conditions wetter than today, because the present Río Parapetí rarely produces discharge events powerful enough to reach the gap.

Although parabolic paleodunes $\left(3-10 \mathrm{~km}^{2}\right)$ occur at several places along the southern margins of the Río Grande paleochannels, they do not match the paleodunes along the Río Parapetí paleochannels in size. Most likely this can be explained with the N-S climatic gradient. Due to a shorter dry season the Río Grande was less prone to sand deflation than the Río Parapetí.

Along the proximal part of its megafan, the Río Grande has laterally eroded the piedmont, forming pronounced erosional scarps along the western and southern margin (Fig. 2, 6): Meander-like curvature of the scarps possibly implies a phase of enhanced meandering under wetter conditions (Fig. 2). In addition to lateral erosion, incision has occurred postdating the major river migration, possibly at the transition to wetter conditions.

In contrast to the Parapetí fan, small episodic secondary drainage channels (cañadas) have formed on the Río Grande megafan within several of the paleochannels as well as in the areas between the paleochannels. The orientation of the cañadas and their coupling to the paleochannels indicate the existence of topographically elevated fluvial ridges (BRIERLEY 1997). These ridges mark the former courses of the Río Grande. Thus, the reconstruction of the paleochannels in the northern part of the megafan can be inferred from the network of cañadas (Fig. 6), whereas in the southern part it is based predominantly on the interpretation of vegetation patterns. In general, cañadas become more frequent towards the northern part of the Río Grande megafan owing to climatic conditions characterized by increased humidity. In addition, the patterns of cañadas on the Río Grande megafan indicate that the avulsion point - the location where the river abandons its channel to occupy a new one - has significantly moved downstream through time (Fig. 6). While this might reflect the natural process of propagating fluvial deposition into actively aggrading sedimentary basins (HaNAGARTH 1993), the large-scale shift of the avulsion point might also document a change towards more constant discharge and sediment supply, and gradual construction of fluvial ridges under wetter climatic conditions (BRISTOw et al. 1999).

The Río Piray (B3) presently flows along the western margin of its megafan. The orientation of cañadas and land-use patterns indicate the presence of paleochannels. Two distinct terrace levels have formed due to incision in the proximal part of the Río Piray megafan. The terrace scarps show meander-like curvature at various places, pointing to enhanced meandering during or following the phase of incision. Meandering might be the result of finer sediment loads and smoothed discharge regimes, possibly under overall wetter conditions (Schumm 2005).

Several authors have reported on the large-scale river shifts of the Río Grande and the Río Parapetí. However, there is no consensus concerning the causes of this phenomenon. Dumont (1996) argues that tectonic subsidence might be the main reason for the shifts. However, the Río Parapetí has shifted from slightly steeper longitudinal gradients $(0,185 \%)$ towards less inclined gradients $(0,165 \%)$, which contradicts fluvial adjustment to tectonic uplift. Horton \& DeCelles 


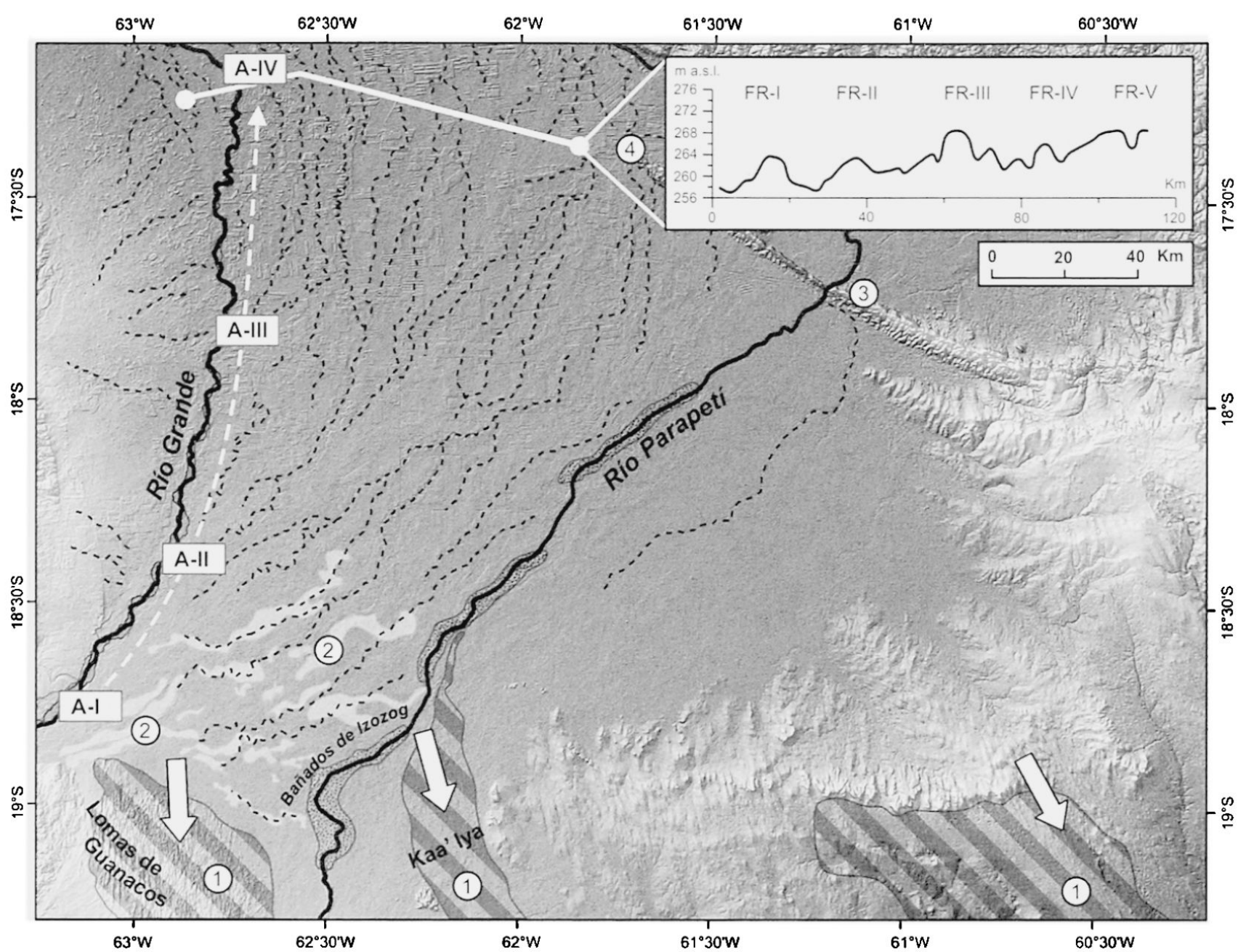

Fig. 6: Overview of the Río Grande megafan and the associated paleodune fields (1), the paleochannels (shaded, 2), antecedent Quimome gap (3), mapped cañadas (black dashed lines), fluvial ridges (FR-I to FR-V) based on topographic transect (4) and northward propagation of the avulsion point (white dashed arrow, A-I to A-IV) (arrow $=$ paleowind direction)

Überblick über den Río Grande «megafan» und die damit assoziierten Paläodünenfelder (1), Paläoflussläufe (schattiert, 2), der antezedente Quimome Flussdurchbruch (3), die kartierten "cañadas» (schwarze gestrichelte Linien), Dammufer (FR-I bis FR-V) auf der Basis eines topographischen Transektes (4) und die Verlagerung des "avulsion point» (weisser gestrichelter Pfeil, A-I to A-IV) (Pfeil = Paläo-Windrichtung)

Vue d'ensemble du mégaéventail du Río Grande et des champs de paléodunes qui lui sont associés (1), paléochenaux (ombré, 2), fossé ancien de Quimome (3), "cañadas» cartographiées (lignes noires discontinues), levées fluviatiles (FR-I à FR-V) basées sur le transect topographique (4) et propagation septentrionale du "point d'avulsion» (flèche discontinue blanche, $A-I$ à $A-I V$ ) (la flèche indique la direction du paléovent)

Source: SRTM 90-m data, Global Land Cover Facility http://www.landcover.org.

(2001) suggested stream capture as responsible for channel abandonment and migration without specifying the causes and mechanisms of this process. WERDING (1977) proposed that the successive northward channel displacement could be explained by enhanced aeolian accumulation along the southern channel margin under dry climatic conditions. The relatively small number and extent of paleodunes along the Río Grande paleochannels in comparison to the Parapetí paleochannels cast doubt on this mechanism being responsible for large-scale shifts in both megafans. In addition the northward displacement of the avulsion point is not explained by enhanced dune accumulation alone. HanagarTh (1993) points out that increased sedimentation rates could accelerate the process of channel migration on the Río Grande megafan. Within the context of the geomorphological framework and the manifold indicators of climatic change, increased 


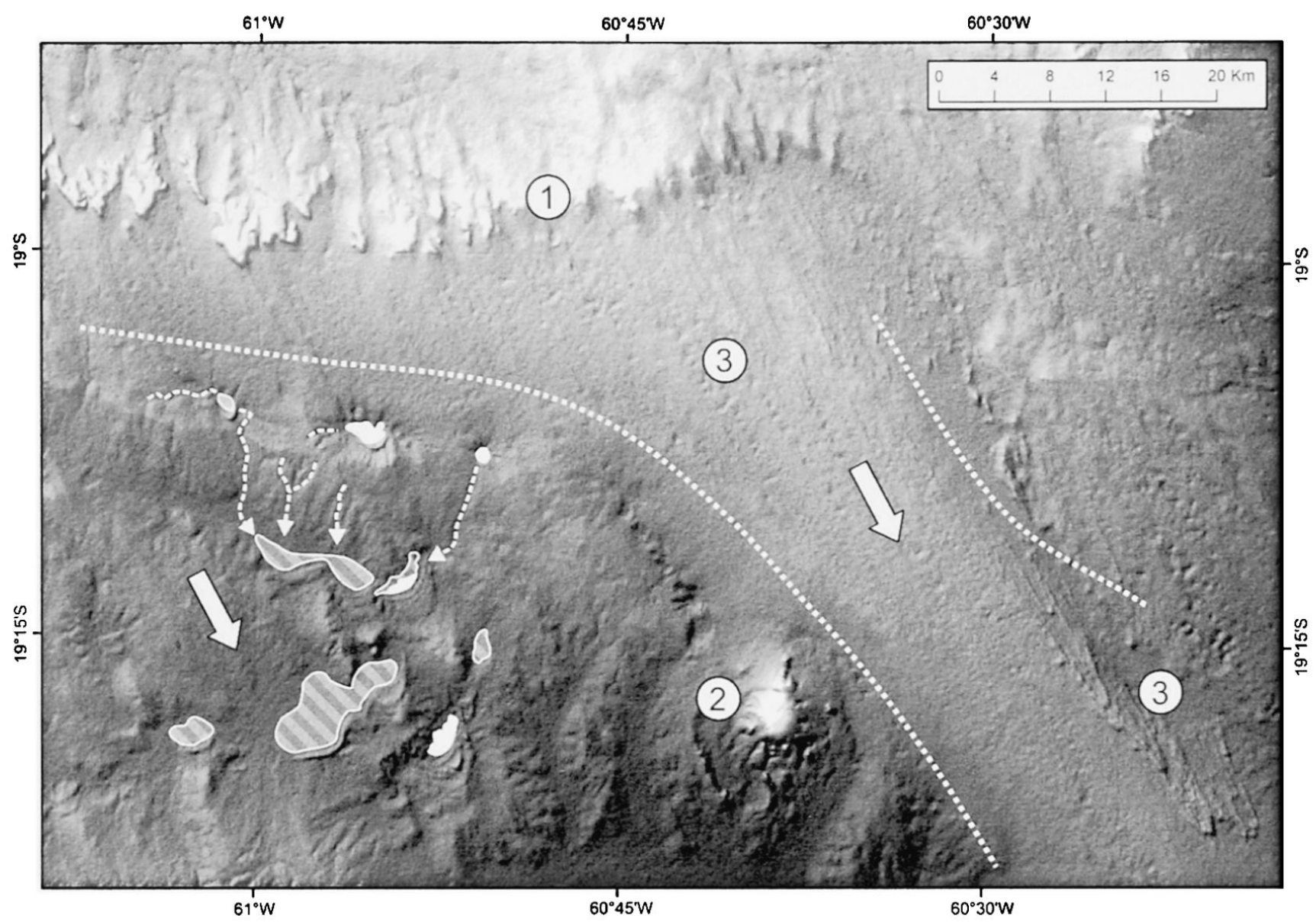

Fig. 7: Cuesta (1), mesa (2) and assumed sand-ramp with paleodunes (dotted, 3); note paleolake basins (hatched) and present saline lakes (white) with lunette paleodunes and incised drainage network between basins (dashed lines) (arrow $=$ paleowind direction)

Schichtstufe (1), Schichtberg (2) und vermutete Sandrampe mit Paläodünen (gepunktet, 3); Paläoseebecken (gestreift) und aktuelle Salzseen mit Lunette-Paläodünen und eingetieftem Gewässernetz zwischen den Becken (gestrichelt) $($ Pfeil = Paläo-Windrichtung)

Cuesta (1), mesa (2) et zone hypothétique de paléodunes (pointillés, 3); bassins paléolacustres (hachuré) et lacs salés actuels (en blanc) avec paléodunes et réseaux incisés de drainage entre les bassins (lignes discontinues) (la flèche indique la direction du paléovent)

Source: SRTM 90-m data, Global Land Cover Facility http://www.landcover.org.

sedimentation rates resulting from climatic and paleohydrological changes could have substantially altered the fluvial regime of the megafan rivers and are likely responsible for the large-scale channel shifts.

\subsection{Uplands (structural high)}

In contrast to the Subandean zone or the Brazilian shield, the structural high corresponding to the Andean forebulge does not have a well-developed drainage network. The most striking features are the W-E orientated cuesta (escarpment) of Mesozoic and Palaeozoic rocks and the isolated mesa of the Cerro San Miguel, representing geomorphological evidence for the long erosional history of these upland areas (Fig. 7).
The dissection of the cuesta essentially follows a NW-SE direction. To the south, an elongated, ramplike and topographically elevated area extends in NW-SE direction to Paraguay (Fig. 7). Several fields of parabolic paleodunes are superimposed on top of this ramp. These paleodunes can be interpreted as the product of past deflation from the Río Grande megafan, aeolian transport over the uplands and deposition below the southern rim of the cuesta. In this context the ramp-like feature is assumed to represent a multiphase sand-ramp from repeated phases of aeolian deposition, giving evidence for the importance of aeolian processes in long-term landscape evolution of the entire EBL. 

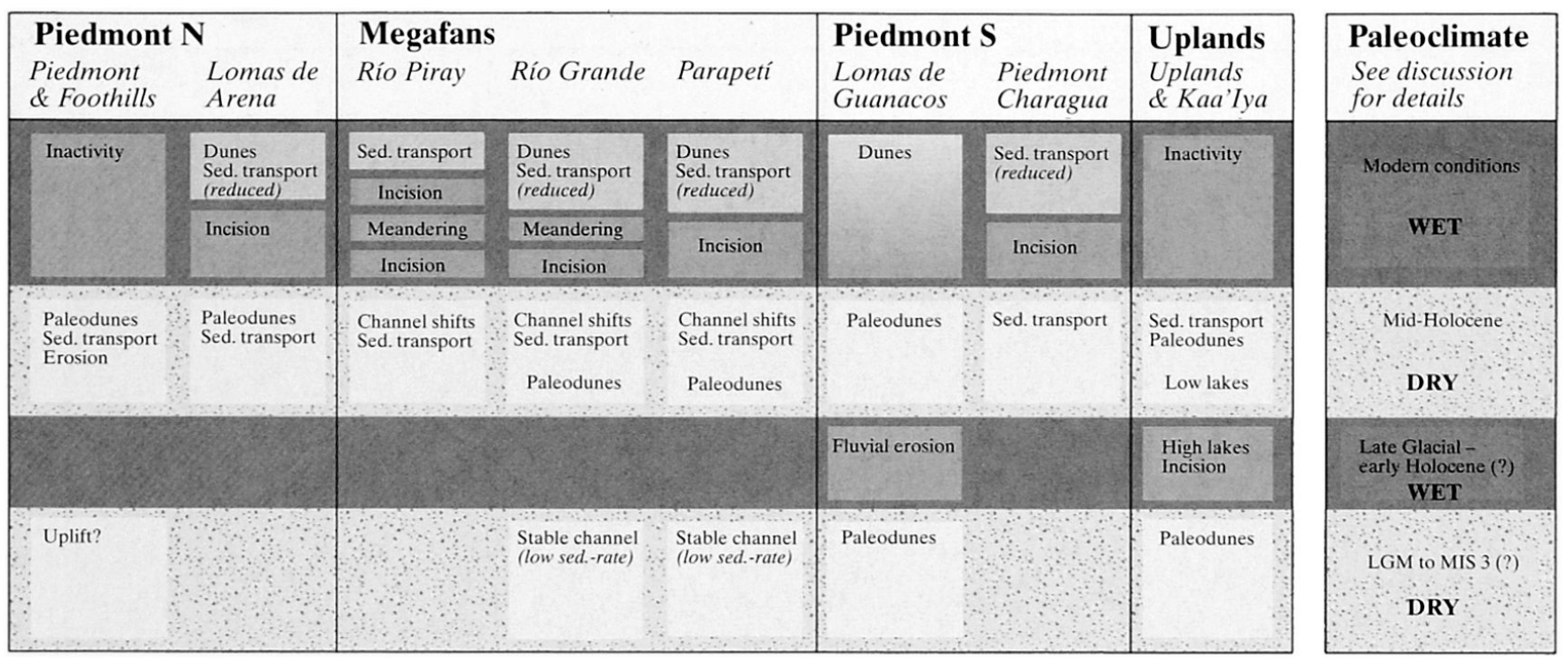

Fig. 8: Sequential landscape evolution as observed for the geomorphological units of the study area and the tentative correlation to paleoclimatic phases (grey shades and black dots)

Sequentielle Landschaftsgeschichte für die geomorphologischen Grosseinheiten im Untersuchungsgebiet und die vorläufige Korrelation mit Paläoklimaphasen (grau schattiert und gepunktet)

Evolution séquentielle des unités géomorphologiques de la zone d'étude et corrélation possible avec les phases paléoclimatiques (ombre grise et pointillés)

A series of small lake basins occurs in the area between the cuesta and the Paraguayan border. Most of the basins are presently covered by forest; few of them contain seasonally inundated saline lakes and salt flats (Fig. 7). The basins do not seem to be integrated into an active drainage network. However, several incised valleys/gorges characterize the former drainage network within the lake catchment areas (Fig. 7). It is assumed that higher lake levels, overflowing and incision prevailed under substantially wetter climatic conditions. Along the south-eastern rim of the basins, ridges of up to 10 meters height have been detected and interpreted as parabolic paleodunes (lunette dunes). All of these paleodunes are presently inactive and covered by forest. Their formation most likely documents increased aeolian activity during dry conditions pre-dating modern conditions, which favour forest growth.

\section{Discussion}

The inventory of landforms presented in this study provides manifold evidence for changing geomorphic processes in Eastern Bolivia during the late Quaternary. Figure 8 summarizes the sequential succession of landforms and associated processes for each investigated geomorphological unit. However, only a tentative correlation can be accomplished, because very few absolute age datings are available so far. Nevertheless, a careful interpretation is attempted in order to correlate events and distinguish phases of landscape evolution.

The concept of landscape stability and activity (RoHDENBURG 1970) uses the intensity and spatial distribution of geomorphic processes (activity and stability) as an indicator for paleoecological conditions. Due to the complexity of feedbacks within the geomorphic system and the difficulties to define thresholds, the effects of climate changes do not only depend on the direction of the change (e.g. from dry to wet) but also on the climatic and geoecological conditions before the change (e.g. total precipitation, seasonality) (Thомаs 2004; Wolman \& Gerson 1978). Therefore, the discussion of landscape evolution and climate history is restricted to the identification of regional sequences of events and landforms, providing a large-scale paleogeoecological frame rather than quantitative paleoclimatic data for the Eastern Bolivian lowlands.

Geomorphological activity in Eastern Bolivia is presently restricted to a limited number of locations. The overall stable landscape (forest cover, inactivity of drainage channels) is an actualistic example for relatively wet climatic conditions. The onset of modern climatic conditions occurred around $3 \mathrm{ka}$ BP in Northeastern Bolivia (Burbridge et al. 2004; Mayle et al. 
2000) and in Rondônia (DE Freitas et al. 2001; PesSENDA et al. 1998), and around $4 \mathrm{ka} \mathrm{BP}$ in the Subandean cloud forests (MourguiarT \& LEDru 2003), suggesting relative landscape stability in the study area within the last $4 \mathrm{ka}$.

In contrast, the observation of numerous paleodune fields and the wide-spread shifts of the floodouts and paleorivers document a generally active landscape under more arid climatic conditions. The reduction of vegetation cover probably enhanced erosion in the catchment areas (e.g. the Subandean foothills, Cordillera Oriental) and reduced infiltration capacity. The resulting high-magnitude and low-frequency run-off events (Wolman \& MiLLER 1960) transported large quantities of coarse sediment onto the piedmont and the megafans, causing rapid sedimentation and channel shifting. Simultaneously, aeolian activity favoured by the reduced vegetation cover and the existence of extensive deflation areas lead to the formation of paleodune fields.

The mid-Holocene ( $8-3 \mathrm{ka})$ in Central South America has been reported to be arid, with widespread sand accumulation of the fluvial systems (BARBOzA et al. 2000; KRUCK 1996), the expansion of savanna type vegetation (De Freitas et al. 2001; Pessenda et al 1998) and frequent forest fires (MourguiarT \& LEDRU 2003; SERVANT et al. 1981). Therefore, the above findings have been tentatively correlated with this midHolocene arid period. This correlation is supported by several preliminary radiocarbon dates on charcoal from fluvio-aeolian sands near Santa Cruz $(4880 \pm 20$ ${ }^{14} \mathrm{C}$ yr BP, $5090 \pm 40{ }^{14} \mathrm{C}$ yr BP$)$, Cabezas $\left(6580 \pm 40{ }^{14} \mathrm{C}\right.$ yr BP) and Charagua $\left(4220 \pm 35{ }^{14} \mathrm{C}\right.$ yr BP, $4950 \pm 35$ ${ }^{14} \mathrm{C}$ yr BP), as well as from aeolian sands at Pelícano $\left(4860 \pm 30{ }^{14} \mathrm{C}\right.$ yr BP, compare Fig. 2).

At some places the geomorphological evidence points to increased humidity in the study area, preceding the highly active interval of sediment transport and dune formation. This is the case for the markedly smoothed morphology of the older dune generations, which must have undergone a time of erosion and reshaping, and the paleolake basins, which document even wetter conditions than today, possibly because of a significant increase of precipitation during the dry season. Despite of the limited number of observations, these findings corroborate previous studies reporting increased moisture availability in the Paraguayan Chaco (BARBOZA et al. 2000; KRUCK 1996) and the Subandean cloud forest (Mourguiart \& LEDru 2003) during the Late Glacial and the transition into Holocene.

Large paleodune fields along the southern margins of the megafans (Río Grande, Río Parapetí) document long time intervals of aeolian activity and constant sediment supply from the megafan rivers. The position of the Río Grande and the Río Parapetí should have been relatively stable, lacking frequent and large-scale channel shifts. This indicates intense discharge events and high transport capacities. In fact, WERDING (1977) notes the existence of coarse fluvial gravel throughout the Río Grande megafan. An overall much more torrential fluvial regime has been reported from several tropical rivers in lowland South America during marine isotope stage 3 (MIS 3) (LATrubesse 2003). Whether the older paleodune generations indeed correspond to MIS 3 or to the last glacial maximum (LGM) and early Late Glacial cannot be decided on the basis of the available data. However, several preliminary radiocarbon dates on charcoal from fluvial sands at Santa Cruz $\left(15140 \pm 70{ }^{14} \mathrm{C}\right.$ yr BP $)$ and Cabezas $\left(18700 \pm 90{ }^{14} \mathrm{C}\right.$ yr BP $)$ indicate aridity in Eastern Bolivia during the LGM and early Late Glacial.

\section{Conclusions}

Based on detailed field work and remote sensing data it has been shown that the thorough description and interpretation of landforms and geomorphic processes has the potential to considerably contribute to the reconstruction of landscape evolution and climate history. In combination with existing records of climate change an overall picture of the late Quaternary could be drawn for the central part of South America. The results presented in this study are the basis for further paleogeoecological studies. These focus on specific locations and include the establishment of absolute chronologies for the succession of processes and events.

\section{Literature}

Agrotecnologica Amazonica (Agteca) (2005): Climate. - http://www.agteca.com/climate.htm 13.01.2005. BAKER, V.R. (1986): Regional landform analysis. - In: ShorT, N.M.S. \& R.W.J. BLAIR (eds): Geomorphology from space. A global overview of regional landforms. Washington, D.C.: NASA Scientific and Technical Information Branch, http://disc.gsfc.nasa.gov/geomorphology/GEO_1/GEO_CHAPTER_1.shtml 22.6.2006.

Barboza, F., Geyh, M.A., Hoffmann, R., Kruck, W., Medina, A.N., Merkt, J. \& C. Rojas (2000): Soil formation and Quaternary geology of the Paraguayan Chaco - thematic mapping. - In: Zeitschrift für angewandte Geologie, Sonderheft 1:49-53.

Barsch, D. \& H. LiedtKe (1980): Principles, scientific value and practical applicability of the geomorphological map of the Federal Republic of Germany at the scale of 1:25000 (GMK 25) and 1:100000 (GMK 100). - In:Zeitschrift für Geomorphologie, Neue Folge, Supplementband 36: 296-313. 
BERRI, G.J. \& J.B. InZUnZa (1993): The effect of the low-level jet on the poleward water vapour transport in the central region of South America. - In: Atmospheric environment 27A, 3: 335-341.

BRIERLEY, G.J. (1997): What is a fluvial levee? - In: Sedimentary geology 114:1-9.

Bristow, C.S., Skelly, R.L. \& F.G. Ethridge (1999): Crevasse splays from the rapidly aggrading, sand-bed, braided Niobara River, Nebraska: effect of base-level rise. - In: Sedimentology 46: 1029-1047.

Burbridge, R.E., Mayle, F.E. \& T.J. Killeen (2004): Fifty-thousand-year vegetation and climate history of Noel Kempff Mercado National Park, Bolivian Amazon. - In: Quaternary research 61, 2: 215-230.

Coltrinari, L. (1993): Global Quaternary changes in South America. - In: Global and planetary change 7, 1-3: 11-23.

De Freitas, H.A., Pessenda, L.C.R., Aravena, R., Gouveia, S.E.M., De Souza Ribeiro, A. \& R. Boulet (2001): Late Quaternary vegetation dynamics in the Southern Amazon Basin inferred from Carbon isotopes in soil organic matter. - In: Quaternary research $55,1: 39-46$.

Dumont, J.F. (1996): Neotectonics of the SubandesBrazilian craton boundary using geomorphological data: the Marañon and Beni basins. - In: Tectonophysics 259, 1-3: 137-151.

Garreaud, R.D. (2000): Cold air incursions over subtropical South America. Mean structure and dynamics. - In: Monthly weather review 128: 2544-2559.

Gubbels, T.L., Isacks, B.L. \& E. Farrar (1993): Highlevel surfaces, plateau uplift, and foreland development, Bolivian Central Andes. - In: Geology 21, 8: 695-698.

Hanagarth, W. (1993): Acerca de la geoecología de las sabanas del Beni en el noreste de Bolivia. - La Paz: Instituto de Ecología.

Hinsch, R., Krawczyk, C.M., Gaedicke, C., Giraudo, R. \& D. Demuro (2002): Basement control on oblique thrust sheet evolution. Seismic imaging of the active deformation front of the Central Andes in Bolivia. - In: Tectonophysics 355, 1-4: 23-39.

Horton, B.K. \& P.G. DeCelles (1997): The modern foreland basin system adjacent to the Central Andes. - In: Geology 25, 10: 895-898.

Horton, B.K. \& P.G. DeCelles (2001): Modern and ancient fluvial megafans in the foreland basin system of the Central Andes, southern Bolivia. Implications for drainage network evolution in fold-thrust belts. - In: Basin research 13: 43-63.

Ibisch, P.L., Beck, S.G., Gerkmann, B. \& A. Carretero (2004): Ecoregions and ecosystems. - In: IBISCH, P. L. \& G. MÉridA (eds): Biodiversity: the richness of Bolivia. State of knowledge and conservation. - Santa Cruz de la Sierra, Bolivia: Editorial F.A.N.: 47-88.

IrIONDO, M. (1993): Geomorphology and late Quaternary of the Chaco (South America). - In: Geomorphology 7, 4: 289-303.
IsACKs, B.L. (1988): Uplift of the Central Andean plateau and bending of the Bolivian orocline. - In: Journal of geophysical research 93, B4: 3211-3231.

JoRDAN, E. (1981): Die rezenten Dünengebiete Boliviens und ihre regional-genetische Differenzierung. - In: Würzburger geographische Arbeiten 53: 159-194.

KRUCK, W. (1996): Pleistoceno superior y holoceno del Chaco paraguayo. - In: Memorias del XII Congreso Geológico de Bolivia, Tarija, Bolivia: 1217-1220.

LATRUBESSE, E.M. (2003): The late Quaternary palaeohydrology of large South American fluvial systems. - In: Gregory, K.J. \& G. Benito (eds): Palaeohydrology. Understanding global change. - Chichester: Wiley: 193-212.

Leier, A.L., DeCelles, P.G. \& J.D. Pelletier (2005): Mountains, monsoons, and megafans. - In: Geology 33, 4: 289-292.

Mayle, F.E., Burbridge, R. \& T.J. Killeen (2000): Millennial-scale dynamics of southern Amazonian rain forests. - In: Science 290, 5500: 2291-2294.

McKeE, E.D. (1979): Introduction to a study of global sand seas. - In: MCKeE, E.D. (ed.): A study of global sand seas. - Washington, D.C.: United States Government Printing Office: 1-19.

Mourguiart, P. \& M.-P. Ledru (2003): Last glacial maximum in an Andean cloud forest environment (Eastern Cordillera, Bolivia). - In: Geology 31, 3: 195-198.

Nogues-Paegle, J., Mechoso, C.R., Fu, R., Berbery, E.H., Chao, W.C., Chen, T.-C., Сook, K., Diaz, A.F., Enfield, D., Ferreira, R., Grimm, A.M., Kousky, V., Liebmann, B., Marengo, J., Mo, K., Neelin, J.D., Paegle, J., Robertson, A.W., Seth, A., Vera, C.S. \& J. Zhou (2002): Progress in Pan American CLIVAR research. Understanding the South American monsoon. - In: Meteorologica 27, 1-2: 3-32.

Pessenda, L.C.R., Gouveia, S.E.M., Gomes, B.M., Aravena, R., Ribeiro, A.S. \& R. Boulet (1998): The carbon isotope record in soils along a forest-cerrado ecosystem transect. Implications for vegetation changes in the Rondonia state, southwestern Brazilian Amazon region. - In: The Holocene 8, 5: 599-603.

Pezza, A.B. \& T. Ambrizzi (2005): Dynamical conditions and synoptic tracks associated with different types of cold surge over tropical South America. - In: International journal of climatology 25, 2:215 - 241.

Rohdenburg, H. (1970): Morphodynamische Aktivitäts- und Stabilitätszeiten statt Pluvial- und Interpluvialzeiten. - In: Eiszeitalter und Gegenwart 21: 81-96.

Saulo, A.C., Seluchi, M.E. \& M. Nicolini (2004): A case study of a Chaco low-level jet event. - In: Monthly weather review 132, 11:2669-2683.

Sснимм, S.A. (1999): Causes and controls of channel incision. - In: Darby, S.E. \& A. Simon (eds): Incised river channels. Processes, forms, engineering, and management. - Chichester: Wiley: 20-33.

Sснимm, S.A. (2005): River variability and complexity. - Cambridge: Cambridge University Press. 
Servant, M., Fontes, J.-C., Rieu, M. \& J.-F. Saliege (1981): Phases climatiques arides holocènes dans le sud-ouest de l'Amazonie (Bolivie). - In: C.R. Academic Science, Paris, Serie II 292: 1295-1297.

Shukla, U.K., Singh, I.B., Sharma, M. \& S. Sharma (2001): A model of alluvial megafan sedimentation: Ganga Megafan. - In: Sedimentary geology 144, 3-4: 243-262.

SмITH, G.A. (2000): Recognition and significance of streamflow-dominated piedmont facies in extensional basins. - In: Basin research 12, 3-4: 399-411.

Summerfield, M.A. (2000): Geomorphology and tectonics. Introduction. - In: Summerfield, M.A. (ed.): Geomorphology and tectonics. - Chichester: John Wiley: 3-12.

THOMAS, M.F. (2004): Landscape sensitivity to rapid environmental change. A Quaternary perspective with examples from tropical areas. - In: CATENA 55, 2: 107-124.

Tоотн, S. (2000): Downstream changes in dryland river channels. The Northern Plains of arid central Australia. - In: Geomorphology 34: 33-54.

UNIVERSITY OF MARYLAND (2005): Global land cover facility. - http://www.landcover.org 15.10.2005.

U.S. Geological Survey (2005): Earth resources observation \& science (EROS). - http://edc.usgs.gov 15.12.2005.

VERSTAPPEN, H.T. (1977): Remote sensing in geomorphology. - Amsterdam: Elsevier.

Welsink, H.J., Franco, A.M. \& C.G. Oviedo (1995): Andean and pre-Andean deformation. Boomerang Hills area, Bolivia. - In: TANKARD, A.J., SUÁRAZ, R.S. \& H.J. Welsink (eds): Petroleum basins of South America. - Tulsa, Oklahoma: The American Association of Petroleum Geologists: 481-499.

WERDING, L. (1977): Geomorphologie und rezente Sedimentation im Chaco Boreal, Bolivien. - In: Giessener geologische Schriften 12: 429-446.

Wolman, M.G. \& R. Gerson (1978): Relative scales of time and effectiveness of climate in watershed geomorphology. - In: Earth surface processes 3: 189-208.

Wolman, M.G. \& J.P. Miller (1960): Magnitude and frequency of forces in geomorphic processes. - In: Journal of geology 68: 54-74.

ZHOU, J. \& K.-M. LAU (1998): Does a monsoon climate exist over South America? - In: Journal of climate 11: 1020-1040.

\footnotetext{
Abstract: Geomorphological indicators of large-scale climatic changes in the Eastern Bolivian lowlands

This study provides an inventory of geomorphological landforms in Eastern Bolivia at different spatial scales. Landforms and associated processes are interpreted and discussed regarding landscape evolution and paleoclimatic significance. Thereby, preliminary conclusions about past climate changes and the geo-
}

morphic evolution in Eastern Bolivia can be provided.

Fluvial and aeolian processes are presently restricted to a few locations in the study area. A much more active landscape has been inferred from large-scale channel shifts and extensive paleodune systems. Mobilization, transport and deposition of sediments are thought to be the result of climatic conditions drier than today. However, there are also indications of formerly wetter conditions such as fluvial erosion and paleolake basins. In conclusion, the documentation and interpretation of the manifold landforms has shown to contain a considerable amount of paleoecological information, which might serve as the base for further paleoclimatic research in the central part of tropical South America.

\section{Zusammenfassung: Rekonstruktion großflächiger Klimaänderungen im ostbolivianischen Tiefland anhand geomorphologischer Indikatoren}

Die vorliegende Arbeit dokumentiert die geomorphologischen Formen in Ostbolivien. Formen und damit assoziierte Prozesse werden landschaftsgeschichtlich interpretiert und hinsichtlich ihrer paläoklimatischen Relevanz diskutiert. So können erste Aussagen über Klimawandel in der geomorphologischen Entwicklung Ostboliviens getroffen werden.

Die fluviale und aeolische Aktivität ist heute auf kleine Bereiche im Untersuchungsraum beschränkt. Ausgedehnte Paläodünensysteme und grosse Flussumlagerungen deuten auf eine viel aktivere Landschaft in der Vergangenheit hin. Dabei werden die Mobilisierung, der Transport und die Ablagerung der Sedimente als Resultat trockenerer Klimabedingungen interpretiert. Allerdings geben Paläoseen und Anzeichen fluvialer Erosion auch Hinweise auf feuchtere Verhältnisse in der Vergangenheit. Insgesamt hält die Dokumentation und Interpretation der vielfältigen Formen einen beachtlichen Teil an paläoökologischer Information bereit, welche als Ausgangspunkt für weitere paläoklimatische Forschungen im zentralen Teil des tropischen Südamerika dienen kann.

\section{Résumé: Indicateurs géomorphologiques révélateurs} de changements climatiques à grande échelle dans les basses terres de l'est de la Bolivie

Cette étude propose un inventaire des formes géomorphologiques de l'est de la Bolivie à différentes échelles. Les formes du relief et les processus qui leur sont associés sont interprétés et discutés en regard de l'évolution du paysage et de son importance paléoclimatique. Ce faisant, il devient possible de tirer des conclusions préliminaires quant aux changements climatiques anciens et à l'évolution géomorphologique de l'est de la Bolivie. 
Bien que les processus fluviatiles et éoliens soient aujourd'hui limités à un nombre restreint de sites dans la zone d'étude, des observations à plus petite échelle montrent des chenaux concernés par des changements importants et des systèmes paléodunaires étendus. La mobilisation, le transport et le dépôt des sédiments résultent alors de conditions climatiques plus sèches qu'aujourd'hui. On trouve néanmoins également des preuves de conditions plus humides, telles que de l'érosion fluviatile et des bassins paléolacustres. En conclusion, l'analyse et l'interprétation des nombreuses formes du relief fournissent un nombre considérable d'informations paléoécologiques, lesquelles pourraient servir de base à d'autres recherches paléoclimatiques dans la partie centrale de l'Amérique du Sud tropicale.

Dipl.-Geogr. Jan-Hendrik May, Institute of Geography, University of Berne, Hallerstrasse 12, CH-3012 Berne, Switzerland.

e-mail: may@giub.unibe.ch

Manuskripteingang/received/manuscrit entré le 15.2.2006

Annahme zum Druck/accepted for publication/accepté pour l'impression: 23.6.2006 